\title{
Improved logistics service quality for goods quality delivery services of companies using analytical hierarchy process
}

\author{
Popy Riliandini' ${ }^{1}$, Erika Noor Dianti ${ }^{2}$, Sayidah Rohmatul Hidayah ${ }^{3}$, Dwika Ananda Agustina Pertiwi ${ }^{4}$ \\ ${ }^{1}$ Informatics Department, Universitas Sebelas Maret \\ ${ }^{2,3,4}$ Computer Science Department, Universitas Negeri Semarang
}

\begin{tabular}{l} 
Article Info \\
\hline Article history: \\
Received Jan 28, 2021 \\
Revised Feb 28, 2021 \\
Accepted March 17, 2021 \\
\hline
\end{tabular}

\section{Keywords:}

Logistic of company Logistic service quality Decision making AHP

\begin{abstract}
Logistics plays a role in the smooth transaction between companies because it is a facilitator of buying and selling goods and services to fulfill the supply orders of consumer companies. This study aims to analyze how the impact of improved Logistic Service Quality (LSQ) for quality of goods delivery services by using LSQ dimensions from previous research. Sample data is obtained through the dissemination of questionnaires which are then processed quantitatively with convergent validity and reliability tests. Data processing with a sample count of 61 respondents. The results of this study show that there is the main dimension of logistic service quality in improving the quality of service, namely ordering condition, time, and information quality. Each comparison factor is tested for consistency using the Analytical Hierarchy Process (AHP), each of the main criteria has a consistency value of less than 0.1 so that the main criteria tested have a consistent comparison matrix and can be the basis of decision making for companies in choosing alternative criteria priorities.
\end{abstract}

This is an open access article under the CC BY-SA license.

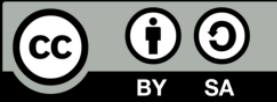

\section{Corresponding Author:}

Popy Riliandini,

Informatics Department,

Universitas Sebelas Maret,

Jl. Ir. Sutami No.36, Kentingan, Kec. Jebres, Surakarta, Indonesia.

Email: popy.riliandini28@student.uns.ac.id

\section{INTRODUCTION}

The development of industrial companies in Indonesia is now increasing rapidly with the influence of advances in information technology. Especially in the field of goods delivery services which is the process framework of a raw material supplier company industrial company [1], [2]. Judging from the rapid development of the industry is one of the factors that the logistics industry will be on the verge of growth in manufacturing, retail, and real estate that began to emerge to the surface [3].

Logistics plays a role in the smooth transaction between companies because it is a facilitator of buying and selling goods and services to fulfill the supply orders of consumer companies. Customer satisfaction is assessed from the quality of service, where a good delivery service is determined by the concept of logistics owned [4], [5]. So, in the logistics of delivery of goods punctuality and place affects the satisfaction of consumers.

In this study, the author tried to apply the AHP method in the case of company problems, namely to know the influence of LSQ on goods delivery service companies. Previous research [6]-[9] that on the relationship between the quality of logistics services with a special emphasis on determining factors as well as customer satisfaction which also contains expectations from customers towards improving the quality of 
logistics services. By applying the AHP and LSQ methods will be tried to know the sectors that contribute predominantly to the company so that the strategy to determine the quality of services in accordance with the conditions and capabilities of the company can be done using the concept of supporting the decision.

LSQ is an interconnected quality construction process, where the construction is reliable and valid in all customer segments. The emphasis is placed on each of the different constructions in several customer segments. Based on the scale of LSQ, supplier companies can understand the desire and expectations of customers in improving the quality of service [10], [11].

In improving the quality of goods delivery services, several alternative criteria focus on how the condition of supply orders, the speed of delivery of supply goods, and the quality of information delivery services when responding to consumer companies, so that good communication is established. The criteria of improving the quality of services will be weighted using the information of a company [12], [13].

Service quality measurement intends to evaluate the performance of supply goods delivery services with selected dimensions. Measurement dimensions can be taken from how the level of customer satisfaction. In a previous study [14]-[16] from the observation process it was obtained that the most significant criterion in improving customer satisfaction and comfort was the accuracy of order conditions.

Judging from the importance of improving the quality of goods delivery services, therefore we then conduct this research, intending to gain the main criteria weight based on the dimensions of LSQ in improving logistics services delivery of goods.

\section{METHOD}

The quantitative approach used in this study, quantitative method is an approach used for the research of certain populations or samples and based on the philosophy of positivism [16], after the data is collected then the data is analyzed which is quantitatively used as an instrument in this study.

This study using data retrieval techniques through the dissemination of questionnaires will then be quantitatively tested with convergent validity and reliability tests using SPSS applications. The data collection process uses questionnaires as instruments that are distributed to companies that use logistics services. The questionnaire is a technique of collecting sample data from respondents through the instrument of questions provided by researchers.

In order to obtain information there are steps in collecting data that is by making a questionnaire consisting of question instruments that correspond to the specified research variables, next determine the respondent to fill out a questionnaire that meets the criteria that have been determined, before filling out the questionnaire respondents are given the procedure of filling out the questionnaire and the purpose of this study, after filling out the questionnaire then the completeness of the questionnaire data, if the data is incomplete then the data will not be used as research sample data. The questionnaire data is tailored to the dimensions of LSQ from previous research by [15], [16]. Weighting criteria by using Multi-Criteria Decision Making (MCDM) namely AHP.

The object of this research sample is the company that owns the goods and users of logistics services delivery of goods. Characteristics of the company that we choose in this study include: (a) companies that often utilize logistics services at least one year; (b) the existence of delivery of goods in a year occurs twice delivery; (c) never get shipments of goods that are not appropriate; (d) through the website, the company utilizes logistics services. As for the framework of research can be seen in Figure 1.

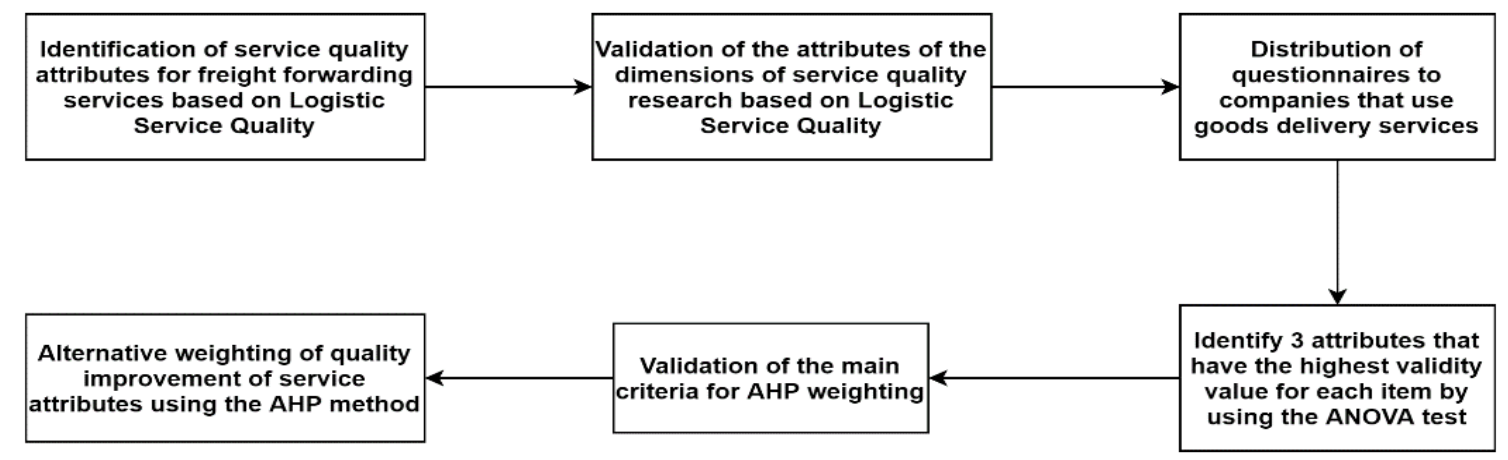

Figure 1. Framework of research 
The next step is to analyze the factors that make consumers dissatisfied with the quality of services provided, the choice of criteria as an alternative weighting sample. Identify criteria tailored to Logistic Service Quality to review the main criteria to be taken. Then weighting is carried out on each alternative based on the

main criteria that have been identified [17]-[19]. This weighting is done by supporting the AHP decision method, where the alternative and comparison of each criterion are inputted in the AHP and it is considered that it has not been able to meet customer satisfaction is the output attribute of LSQ [16].

\section{RESULT AND DISCUSSION}

Sample data was obtained through the dissemination of questionnaires at a company that utilizes the logistics system as the fulfillment of the supply of raw materials production, where the sample data obtained by 61 respondents who are then processed through validity and reliability tests to find out the average of each attribute questionnaire using the method of statistical quantity analysis ANOVA and the results can be seen Table 1.

Table 1. Convergent validity test

\begin{tabular}{|c|c|c|c|}
\hline Construct & Items & Mean & Std. Deviation \\
\hline Information & Ease of accessing service information & 3,97 & 0,73 \\
\hline \multirow[t]{2}{*}{ Quality } & $\begin{array}{l}\text { Accuracy of information from the provider of } \\
\text { goods delivery services (logistics) }\end{array}$ & 3,54 & 0,721 \\
\hline & $\begin{array}{l}\text { Clarity of information from the provider of } \\
\text { goods delivery services (logistics) }\end{array}$ & 3,7 & 0,715 \\
\hline \multirow[t]{3}{*}{ Order Procedure } & $\begin{array}{l}\text { Provided website of the provider of goods } \\
\text { delivery services (delivery of goods) }\end{array}$ & 3,77 & 0,864 \\
\hline & $\begin{array}{l}\text { Delivery service providers do not limit the } \\
\text { volume of }\end{array}$ & 3,44 & 1,025 \\
\hline & Procedure clarity & 3,77 & 0,920 \\
\hline \multirow[t]{3}{*}{ Time } & Time to arrive fast & 4,00 & 0,753 \\
\hline & The promised time is very appropriate & 3,54 & 0,867 \\
\hline & Packing setup speed & 3,56 & 0,786 \\
\hline \multirow[t]{3}{*}{ Order Condition } & Goods up to good condition & 4,13 & 0,806 \\
\hline & Items not damaged & 3,57 & 0,753 \\
\hline & Items not lost & 3,62 & 0,730 \\
\hline Order & Responsiveness in responding to problems & 3,51 & 0,977 \\
\hline Discrepancies & Be agile in dealing with problems that arise & 3,43 & 0,939 \\
\hline Handling & Provide proper compensation & 3,61 & 0,954 \\
\hline
\end{tabular}

From the results of the convergent validity test, there is an average value of each criterion, taken the highest mean value based on the results among others, order condition with a mean value of 4.13 , then time with a mean value of 4.00 , and information quality with a mean value of 3.78 . Where the three ratings mean value is used as the main criteria for weighting calculation on the method of supporting the decision.

Next, a correlation test is conducted to determine the strength and direction of the linear relationship of the correlation between variables by comparing the calculated $\mathrm{R}$ and $\mathrm{R}$ values of table. The result is said to

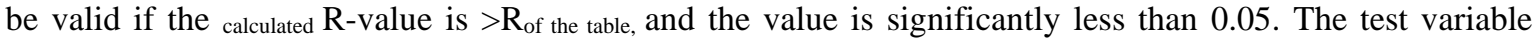
correlations can be seen Table 2 .

From the reliability test in Table 2, getting the result of Cronbach's Alpha value of each criterion greater than 0.6 then we can conclude that the level of stability of measurable data is high and reliable. The reliability test can be seen Table 3. From this table, got a value of Cronbach's Alpha greater than 0.6 then it can be concluded that the level of stability of measurable data is high and reliable. The next step is data processing for the determination of priority weights of each attribute using the AHP method, this determination aims to know the consistency of each of the main criteria as an attribute in improving the quality of logistics services delivery of goods for companies seen from the point of view of the main criteria. 
Table 2. Test variable correlations

\begin{tabular}{cccc}
\hline Items & Pearson Correlation & Sig. & $\mathrm{N}$ \\
\hline IQ1 & 1 & 0,00 & 61 \\
IQ2 & 0,587 & 0,00 & 61 \\
IQ3 & 0,482 & 0,00 & 61 \\
OP1 & 0,469 & 0,00 & 61 \\
OP2 & 0,407 & 0,01 & 61 \\
OP3 & 0,00 & 61 \\
T1 & 0,599 & 0,00 & 61 \\
T2 & 0,472 & 0,00 & 61 \\
T3 & 0,460 & 0,00 & 61 \\
OC1 & 0,519 & 0,00 & 61 \\
OC2 & 0,474 & 0,00 & 61 \\
OC3 & 0,516 & 0,00 & 61 \\
ODH1 & 0,512 & 0,00 & 61 \\
ODH2 & 0,539 & 0,00 & 61 \\
ODH3 & 0,482 & 0,00 & 61 \\
\hline
\end{tabular}

Table 3. Reliability test

\begin{tabular}{ccc}
\hline Items & Cronbach's Alpha & Description \\
\hline IQ1 & 0,915 & Reliabel \\
IQ2 & 0,915 & Reliabel \\
IQ3 & 0,919 & Reliabel \\
OP1 & 0,921 & Reliabel \\
OP2 & 0,920 & Reliabel \\
OP3 & 0,915 & Reliabel \\
T1 & 0,917 & Reliabel \\
T2 & 0,918 & Reliabel \\
T3 & 0,917 & Reliabel \\
OC1 & 0,917 & Reliabel \\
OC2 & 0,918 & Reliabel \\
OC3 & 0,917 & Reliabel \\
ODH1 & 0,912 & Reliabel \\
ODH2 & 0,912 & Reliabel \\
\hline
\end{tabular}

Consistency of assessment on AHP method using Consistency Ratio (CR), formulated:

where:

$$
C R==\frac{C I}{R I}
$$

$$
\mathrm{CI}=\frac{\left(\lambda_{\operatorname{maks}}-n\right)}{n-1}
$$

The following are the results of the calculation of the Consistency Ratio (CR) of each alternative can be seen in Table 4 and 5 ,

Table 4. Eigenvector normalization criteria of order conditions

\begin{tabular}{cccccc}
\hline Criteria & C1 & C2 & C3 & Total & EVN \\
\hline C1 & 2.99 & 7.65 & 19 & 29.64 & 0.6403262985 \\
C2 & 1.26 & 2.98 & 7.65 & 11.89 & 0.2568650368 \\
C3 & 0.5089 & 1.26 & 2.99 & 4.7589 & 0.1028086647 \\
\hline & Overall & & 46.2889 & \\
\hline
\end{tabular}




\begin{tabular}{ccc}
\multicolumn{3}{c}{ Table 5. Consistency ratio of order condition criteria } \\
\hline Emacs & $\mathrm{Ci}$ & $\mathrm{Cr}$ \\
\hline 3.017202828 & 0.008601414162 & 0.01483002442 \\
\hline
\end{tabular}

From Table 5, the criteria ratio of the order condition is $C R<0.1$. So, it can be drawn results in Tables 6 and 7 that the comparison matrix is consistent.

Table 6. Eigenvector normalization criteria delivery speed

\begin{tabular}{cccccc}
\hline Criteria & $\mathrm{C} 1$ & $\mathrm{C} 2$ & $\mathrm{C} 3$ & Total & EVN \\
\hline $\mathrm{C} 1$ & 2.99 & 0.5089 & 1.26 & 4.7589 & 0.1028086647 \\
$\mathrm{C} 2$ & 19 & 2.99 & 7.65 & 29.64 & 0.6403262985 \\
$\mathrm{C} 3$ & 7.65 & 1.26 & 2.98 & 11.89 & 0.2568650368 \\
\hline \multicolumn{7}{c}{ Overall } & & 46.2889 & \\
\hline
\end{tabular}

Table 7. Delivery speed criteria consistency ratio

\begin{tabular}{ccc}
\hline Emacs & $\mathrm{Ci}$ & $\mathrm{Cr}$ \\
\hline 3.017202828 & 0.008601414162 & 0.01483002442 \\
\hline
\end{tabular}

From the consistency table, the ratio of the delivery speed criteria is $C R<0.1$. So it can be drawn results in Tables 8 and 9 that the comparison matrix is consistent.

Table 8. Eigenvector normalization of information quality

\begin{tabular}{cccccc}
\hline Criteria & $\mathrm{C} 1$ & $\mathrm{C} 2$ & $\mathrm{C} 3$ & Total & EVN \\
\hline $\mathrm{C} 1$ & 3 & 11.4 & 1.1 & 15.5 & 0.2115174672 \\
$\mathrm{C} 2$ & 1.1 & 2.98 & 0.32 & 4.4 & 0.06004366812 \\
$\mathrm{C} 3$ & 11.4 & 39 & 2.98 & 53.38 & 0.7284388646 \\
\hline
\end{tabular}

Table 9. Consistency ratio of information quality criteria

\begin{tabular}{ccc}
\hline Emacs & $\mathrm{Ci}$ & $\mathrm{Cr}$ \\
\hline 3.068084061 & 0.03404203057 & 0.05869315615 \\
\hline
\end{tabular}

From the consistency table, the ratio of quality criteria is information that the value $C R<0.1$. So it can be drawn results that the comparison matrix is consistent. Next, the final result of the selection of criteria using multiplication of the results of eigenvector normalization of each criterion tested is $\mathrm{C} 1=0.5008846749$, $\mathrm{C} 2=0.3261559147$ and $\mathrm{C} 3=0.1729594104$.

In criteria 1, alternative 1 ranks first which means excelling in maintaining supply order conditions. Then in criteria 2, alternative 2 is superior to other alternatives in the delivery time/speed criteria. And alternative 3 becomes the first order on criteria 3 that is superior in considering consumers of the company through good quality information. The alternative priority of criterion can be seen in Figure 2 . 


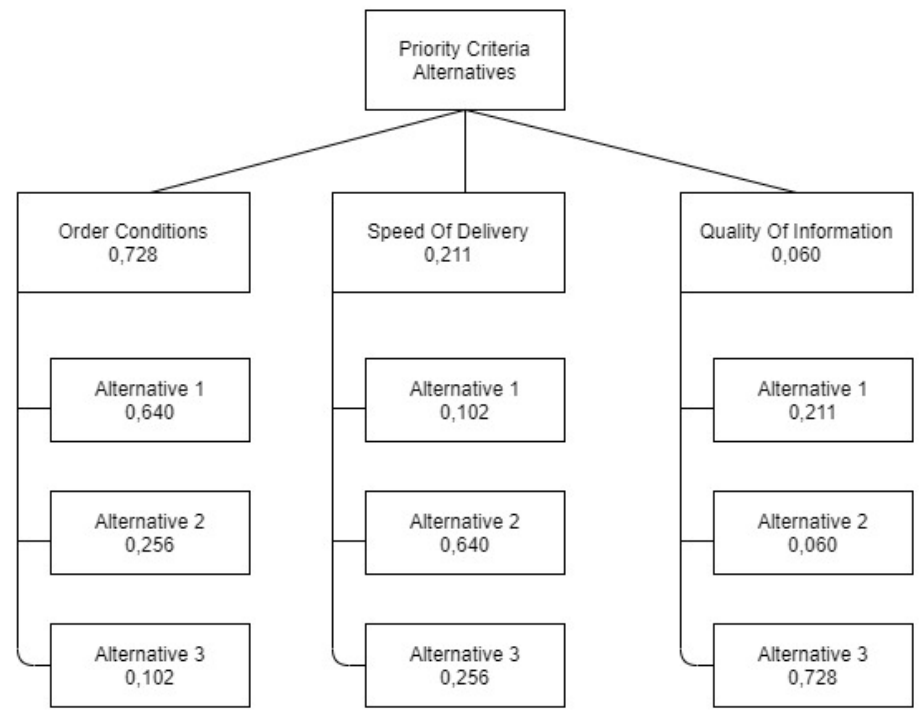

Figure 2. Alternative priority criteria

On the alternative priority chart of criteria, each dimension of the main criteria can be used as a decision-supporting construction in choosing an alternative delivery service company, where the weighting construction decision is tailored to the needs of the consumer company. The alternative priority chart of criteria can be seen Figure 3.

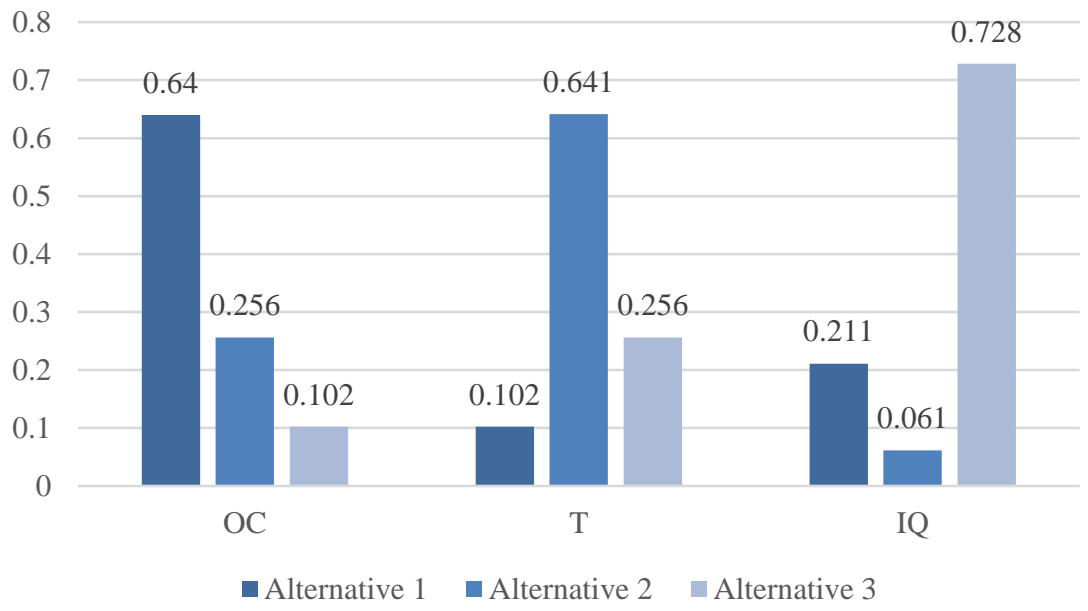

Figure 3. Alternative priority chart of criteria

\section{CONCLUSION}

Research on improving the quality of goods delivery services based on Logistic Service Quality by using sample data obtained through the dissemination of questionnaires in service user companies, obtained from 5 dimensions of LSQ namely Information Quality (IQ), Order Procedure (OP), Time (T), Order Condition (OC), Order Discrepancies Handling (ODH). From sample data obtained processed through AHP decision support method, resulting in three main criteria, namely good condition of goods, speed of delivery of goods, quality of information services. The main criteria of weighting results are factors that can influence in improving the quality of the company's services in the field of logistics of delivery of supply goods.

\section{REFERENCES}

[1] M. C. Cooper and J. T. Gardner, "Building good business relationships: more than just partnering or strategic alliances?," Int. J. Phys. Distrib. Logist. Manag., vol. 23, no. 6, pp. 14-26, 1993, doi: 10.1108/09600039310044876. 
[2] Z. Lemma, K. Sripruetkiat, and I. Nitithanprapas, "Factors affecting sustainability of business relationships in ethiopia banana value chain," J. Austrian Soc. Agric. Econ., vol. 16, no. 05, pp. 83-95, 2020.

[3] R. A. Kahnali and A. Esmaeili, "An integration of SERVQUAL dimensions and logistics service quality indicators (A case study)," Int. J. Serv. Oper. Manag., vol. 21, no. 3, pp. 289-309, 2015, doi: 10.1504/IJSOM.2015.069650.

[4] R. Bouzaabia, O. Bouzaabia, and A. Capatina, "Retail logistics service quality: A cross-cultural survey on customer perceptions," Int. J. Retail Distrib. Manag., vol. 41, no. 8, pp. 627-647, 2013, doi: 10.1108/IJRDM-02-2012-0012.

[5] A. N. Giovanis, P. Tomaras, and D. Zondiros, "Suppliers Logistics Service Quality Performance and its effect on retailers' behavioral intentions," Procedia - Soc. Behav. Sci., vol. 73, pp. 302-309, 2013, doi: 10.1016/j.sbspro.2013.02.056.

[6] I. G. Saura, D. S. Francés, G. B. Contrí, and M. F. Blasco, "Logistics service quality: A new way to loyalty," Ind. Manag. Data Syst., vol. 108, no. 5, pp. 650-668, 2008, doi: $10.1108 / 02635570810876778$.

[7] X.-Y. Zhou, D.-M. Wang, and Y. Liu, "The empirical study of logistics service quality evaluation within electronic retail," 2018, doi: 10.2991/icmesd-18.2018.32.

[8] S. Nugroho, S. Kempa, and T. Wiliater Soaloon Panjaitan, "Logistic service quality and customer satisfaction to customer retention on rice producer industry," SHS Web Conf., vol. 76, p. 01048, 2020, doi: $10.1051 /$ shsconf/20207601048.

[9] M. Er, T. Wasusri, H. M. Astuti, and A. Herdiyanti, "The service quality of Indonesia's logistics service provider in preparation for ASEAN economic community," Lect. Notes Electr. Eng., vol. 349, pp. 647656, 2015, doi: 10.1007/978-3-662-47200-2_68.

[10] J. T. Mentzer, D. J. Flint, and G. T. M. Hult, "Logistics service quality as a segment-customized process," J. Mark., vol. 65, no. 4, pp. 82-104, 2001, doi: 10.1509/jmkg.65.4.82.18390.

[11] A. Sutrisno, E. Andajani, and F. N. Widjaja, "The Effects of Service Quality on Customer Satisfaction and Loyalty in a Logistics Company," KnE Soc. Sci., 2019, doi: 10.18502/kss.v3i26.5360.

[12] W. H. Yu, S. K. Chiu, and C. M. Tung, "The study of evolution among logistic service quality, service compensation and long-term cooperation commitment," Procedia Manuf., vol. 39, pp. 1493-1500, 2019, doi: 10.1016/j.promfg.2020.01.299.

[13] H. M. Jang, P. B. Marlow, and K. Mitroussi, "The effect of logistics service quality on customer loyalty through relationship quality in the container shipping context," Transp. J., vol. 52, no. 4, pp. 493-521, 2013, doi: 10.5325/transportationj.52.4.0493.

[14] A. K. Rahmat and N. Faisol, "Manufacturers satisfaction on logistics service quality: operational, relational and national culture," Procedia - Soc. Behav. Sci., vol. 224, pp. 339-346, 2016, doi: 10.1016/j.sbspro.2016.05.385.

[15] J. Sze, D. O. L. Teik, F. Tiffany, L. F. Kok, and T.Y. Teh, "Logistic service quality among courier services in malaysia,” Int. Conf. Econ. Bus. Innov., vol. 38, pp. 113-117, 2012.

[16] J. S. Y. Ho, D. O. L. Teik, F. Tiffany, L. F. Kok, and T. Y. Teh, "The Moderating Effect of Local VS. Foreign CourierService Providers on Logistic Service Quality (LSQ)," Int. J. Trade, Econ. Financ., pp. 257-261, 2012, doi: 10.7763/ijtef.2012.v3.210.

[17] M. A. Imron and B. Prasetyo, "Improving algorithm accuracy k-nearest neighbor using z-score normalization and particle swarm optimization to predict customer churn," J. Soft Comput. Explor., vol. 1, pp. 56-62, 2020.

[18] A. R. Safitri and M. A. Muslim, "Improved accuracy of naive bayes classifier for determination of customer churn uses smote and genetic algorithms," J. Soft Comput. Explor., vol. 1, no. 1, pp. 70-75, 2020.

[19] H. A. Prihanditya, "The implementation of z-score normalization and boosting techniques to increase accuracy of c4 .5 algorithm in diagnosing chronic kidney disease," J. Soft Comput. Explor., vol. 5, no. 1, pp. 63-69, 2020. 